\title{
Sistem Informasi Pelayanan Administrasi Kependudukan Berbasis Web Menggunakan Metode Waterfall Di Desa Sidakangen Purbalingga
}

\author{
Nabila Khaerunnisa* ${ }^{* 1}$ Eddy Maryanto ${ }^{2}$, Nur Chasanah ${ }^{3}$ \\ 1,2,3 Informatika, Fakultas Teknik, Universitas Jenderal Soedirman, Indonesia \\ Email: ${ }^{1}$ nabila.khaerunnisa@ mhs.unsoed.ac.id, ${ }^{2}$ eddy.maryanto@ unsoed.ac.id, \\ nur.chasanah@unsoed.ac.id
}

\begin{abstract}
Abstrak
Sistem Informasi Pelayanan Administrasi Kependudukan merupakan sistem berbasis web yang digunakan untuk mengelola proses pelayanan administrasi pembuatan surat-menyurat. Pembuatan surat-menyurat di Desa Sidakangen masih menggunakan pembukuan atau arsip secara manual. Dari pembukuan atau arsip tersebut kemudian di rekap kedalam Microsoft Excel untuk dicetak sebagai laporan, belum lagi petugas akan melayani masyarakat dalam pembuatan surat menyurat sehingga pada prosesnya membutuhkan waktu yang lebih untuk melakukan pelayanan administrasi kependudukan dengan baik. Untuk mengatasi beberapa permasalah tersebut maka perlu dirancang suatu Sistem Informasi Pelayanan Administrasi Kependudukan Berbasis Web sehingga dapat meningkatkan kinerja Perangkat Desa dalam mengolah data - data dan informasi yang dimiliki agar lebih akurat dan efisien, serta dapat menangani permasalahan dalam pelayanan administrasi kependudukan di Desa Sidakangen. Sistem Informasi Pelayanan Administrasi ini menggunakan metode pengembangan Waterfall dengan metode pengujian Blackbox dan MOS (Mean Opinion Score) yang membuktikan bahwa adanya sistem ini masyarakat akan lebih mudah dalam melakukan proses pelayanan administrasi tingkat desa.
\end{abstract}

Kata kunci: Administrasi, Informasi, MySQL, Pelayanan, PHP, Sistem.

\begin{abstract}
The Population Administration Service Information System is a web-based system that is used to manage the administrative service process of making correspondence. Making correspondence in Sidakangen Village still uses manual books or archives. The books or archives are then recapitulated into Microsoft Excel to be printed as a report, not to mention the officers will serve the public in making correspondence so that in the process it takes more time to carry out population administration services properly. To overcome some of these problems, it is necessary to design a Web-Based Population Administration Service Information System so that it can improve the performance of the Village Apparatus in processing the data and information held to be more accurate and efficient, and can handle problems in population administration services in Sidakangen Village. This Administrative Service Information System uses the Waterfall development method with the Blackbox and MOS (Mean Opinion Score) testing methods which proves that the existence of this system makes it easier for the community to process village-level administrative services.
\end{abstract}

Keywords: MySQL, Administrative Services, PHP, Information Systems.

\section{PENDAHULUAN}

Peraturan Menteri Dalam Negeri Nomor 32 Tahun 2006 menjelaskan bahwa Pemerintahan Desa adalah penyelenggaraan urusan pemerintahan oleh Pemerintah Desa dan Badan Permusyawaratan Desa dalam mengatur dan mengurus kepentingan masyarakat setempat berdasarkan asal usul dan adat istiadat setempat yang diakui dan dihormati dalam sistem Pemerintahan Negara Kesatuan Republik Indonesia [1]. Salah satu pemerintahan Desa yang ada di Indonesia adalah Desa Sidakangen yang merupakan bagian dari wilayah Kecamatan Kalimanah, Kabupaten Purbalingga, Provinsi Jawa tengah dengan luas wilayah 94.864 Hektar.

Pada bagian pemerintahan, Desa Sidakangen memiliki kantor desa sebagai sarana pelayanan administrasi kepada masyarakat. Pelayanan administrasi di Desa Sidakangen masih menggunakan pembukuan atau arsip-arsip 
dalam bentuk manual, dari pembukuan atau arsip tersebut kemudian akan di rekap kedalam Microsoft Excel untuk dicetak sebagai laporan, sehingga seringkali terjadi kesalahan bahkan ada arsip yang hilang atau rusak karena terlalu banyaknya arsip yang ada, belum lagi petugas akan melayani masyarakat dalam pembuatan surat menyurat sehingga pada prosesnya membutuhkan waktu yang lebih untuk melakukan pelayanan administrasi dengan baik.

Dari permasalahan tersebut, muncul dampak lain seperti tidak efisiennya waktu yang digunakan untuk memproses pelayanan administrasi kependudukan dalam pencarian data penduduk, serta proses administrasi pembuatan surat 2 pengantar dan surat keterangan yang membutuhkan waktu dan kesulitan untuk mendapatkan laporan administrasi kependudukan yang cepat dan akurat dalam waktu singkat.

Berdasarkan permasalahan yang telah dijelaskan, maka muncul suatu ide untuk membangun Sistem Informasi Pelayanan Administrasi Kependudukan Berbasis Web dimana masyarakat dapat mengajukan pelayanan administrasi secara online sesuai dengan formulir jenis surat yang sudah di sediakan oleh sistem. Dengan adanya sistem ini dapat meningkatkan kinerja Aparat Desa dalam mengolah data - data dan informasi yang dimiliki agar lebih akurat dan efisien, serta dapat meningkatkan pelayanan kepada masyarakat.

\section{METODE PENELITIAN}

Penelitian yang berjudul Pengembangan Sistem Informasi Pelayanan Administrasi Kependudukan Berbasis Web Studi Kasus Desa Sidakangen Purbalingga dilakukan dengan menggunakan metode pengembangan waterfall. Proses pengembangan waterfall ini terdiri dari lima tahap berurutan yaitu sebagai berikut :

a. Wawancara

Dalam metode ini dilakukan wawancara secara langsung dengan pihakpihak yang terkait untuk memperoleh data yang akurat dan relevan agar dapat menghasilkan suatu kebutuhan sistem. Pada penelitian ini, wawancara dilakukan dengan Sekretaris Desa yang bernama Bapak Suhadi, dari hasil wawancara tersebut dapat memperoleh informasi yang terjadi pada sistem pelayanan administrasi kependudukan Desa Sidakangen yang berjalan saat ini.

b. Studi Kepustakaan

Studi kepustakaan merupakan kegiatan untuk menghimpun informasi yang relevan dengan topik atau masalah yang menjadi objek penelitian. Informasi tersebut dapat diperoleh dari buku, jurnal, artikel, dan sumber lainnya. Dengan melakukan studi kepustakaan dapat memanfaatkan semua informasi dan pemikiran yang relevan dengan penelitiannya.

c. Observasi

Pada observasi ini dilakukan pengamatan langsung kegiatan yang ada di Desa Sidakangen Purbalingga untuk mendapatkan data - data yang diperlukan dan mengetahui proses sistem yang berjalan. Data tersebut berupa contoh surat - surat yang dikumpulkan sebagai sampel.

d. Metode Pengembangan Sistem

Metode pengembangan yang digunakan adalah metode waterfall. Metode waterfall merupakan hal yang menggambarkan pendekatan secara sistematis dan juga berurutan (step by step) dimana kemajuan atau perkembangan seperti air terjun yang mengalir ke bawah pada sebuah pengembangan perangkat lunak. Tahapan dengan spesifikasi kebutuhan pengguna requirement analisis, system design, implementation, integration and testing, serta maintenance.

\section{HASIL DAN PEMBAHASAN}

\subsection{Tahap Analisis}

Tahap analisis merupakan tahapan yang dilakukan untuk menganalisis sistem baik kebutuhan fungsional serta non-fungsional yang diperoleh dari hasil observasi dan wawancara dengan Sekretaris Desa Sidakangen, sehingga pengembang sistem mendapatkan gambaran sistem yang ideal untuk menyusun Sistem Informasi Pelayanan Administrasi Kependudukan Berbasis Web ini. Dari hasil wawancara tersebut dapat dibuat user requirements dan system requirements. 
Setelah mengetahui peran pengguna yang terlibat dalam sistem, maka dapat dibuat dalam (URS) User Requirement Spesification. Dapat dilihat pada Tabel 1 berikut.

Tabel 1. User Requirement Spesification

\begin{tabular}{ccc}
\hline User & Kebutuhan User & Kode URS \\
\hline Masyarakat & Melakukan Login dengan username dan password & URS-SIPAK-1 \\
& Membuat akun & URS-SIPAK-2 \\
& Dapat mengubah akun & URS-SIPAK-3 \\
& Dapat melakukan pengajuan surat & URS-SIPAK-4 \\
Dapat melihat status pengajuan surat & URS-SIPAK-5 \\
& Dapat melihat artikel dan profil desa & URS-SIPAK-6 \\
& Dapat mengajukan Kritik dan saran & URS-SIPAK-7 \\
\hline Admin & Melakukan Login dengan username dan password & URS-SIPAK-8 \\
& Dapat menghapus User & URS-SIPAK-9 \\
& Dapat melihat Pengajuan Surat & URS-SIPAK-10 \\
& Dapat mengedit Surat & URS-SIPAK-11 \\
& Dapat Mengkonfirmasi Persetujuan (ACC Surat) & URS-SIPAK-12 \\
& Dapat Mencetak Surat Pengajuan & URS-SIPAK-13 \\
& Dapat mencetak Laporan Surat & URS-SIPAK-14 \\
& Dapat menambahkan artikel kegiatan desa & URS-SIPAK-15 \\
& Notifikasi WhatsApp & URS-SIPAK-16 \\
& Dapat menghapus artikel kegiatan desa & URS-SIPAK-17 \\
& Dapat melihat kritik dan saran & URS-SIPAK-18 \\
\hline Sekretaris & Melakukan Login dengan username dan password & URS-SIPAK-19 \\
Desa & Dapat melihat konfirmasi persetujuan (ACC Surat) & URS-SIPAK-20 \\
& Dapat Menghapus Pengajuan Surat & URS-SIPAK-21 \\
\hline Kepala Desa & Melakukan Login dengan username dan password & URS-SIPAK-22 \\
& Dapat melihat laporan data Pengajuan & URS-SIPAK-23 \\
\hline
\end{tabular}

\subsection{Tahap Desain}

Tahap desain merupakan tahap kedua yang dilakukan ketika tahap analisis sudah selesai dilakukan. Tahap ini bertujuan agar sistem yang dibuat sesuai dengan alur proses bagaimana sistem akan dikembangkan sehingga sistem akan menjadi terarah, dan sesuai dengan hasil yang diinginkan oleh pihak Aparat Desa. Tahap desain pada Sistem Informasi Pelayanan Administrasi Kependudukan menggunakan beberapa diagram untuk menjelaskan aplikasi yang akan dibuat yaitu Data Flow Diagram dan Entity Relationship Diagram.

1. DFD Level 0

Diagram level 0 (Diagram Konteks) menggambarkan garis besar jalannya data atau informasi secara keseluruhan yang terdapat dalam sistem. DFD level 0 terdiri dari 4 entitas yang terlibat yaitu Masyarakat, Admin, Kepala Desa, dan Sekretaris Desa.

2. DFD Level 1

DFD Level 1 merupakan penjabaran dari DFD level 0 yang telah tergambar secara rinci dari kerja sistem dengan membagi sistem menjadi beberapa proses yang saling berkaitan. Proses tersebut dibagi menjadi 7 proses yaitu : proses login, proses kelola pengajuan, proses kelola user, proses kelola surat, proses kelola artikel, proses kritik dan saran, dan proses membuat laporan. 


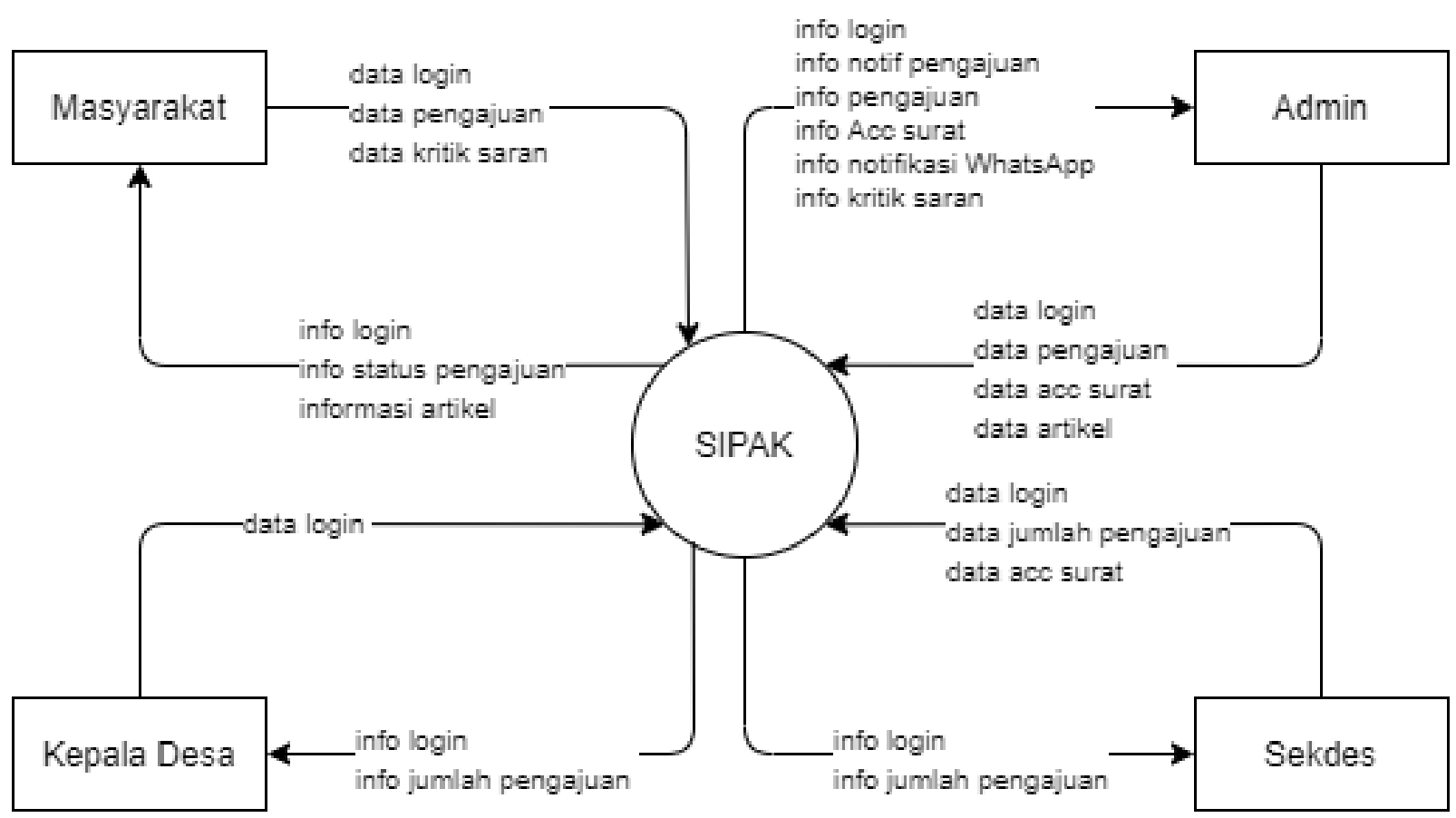

Gambar 1. DFD Level 0

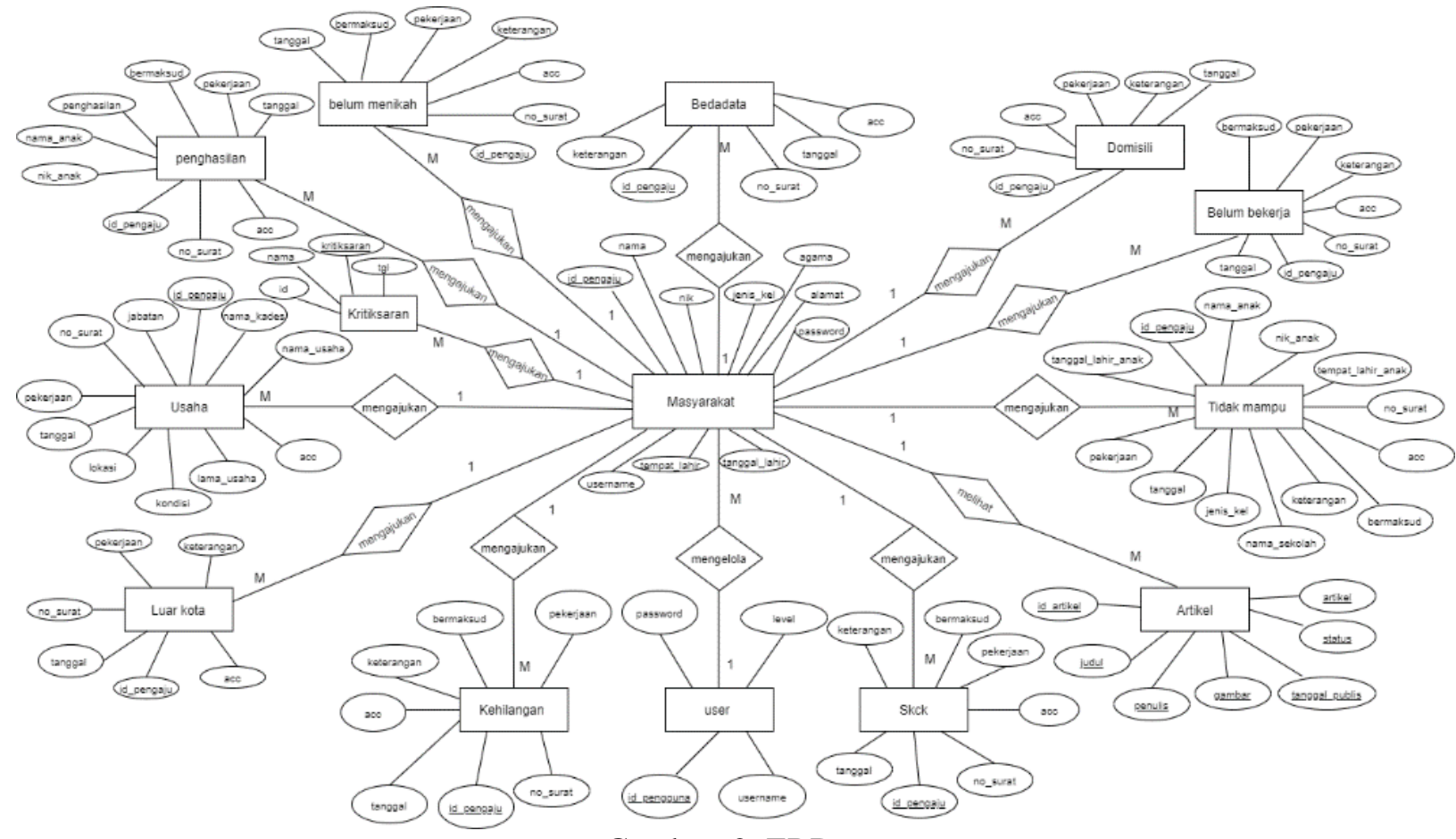

Gambar 2. ERD 


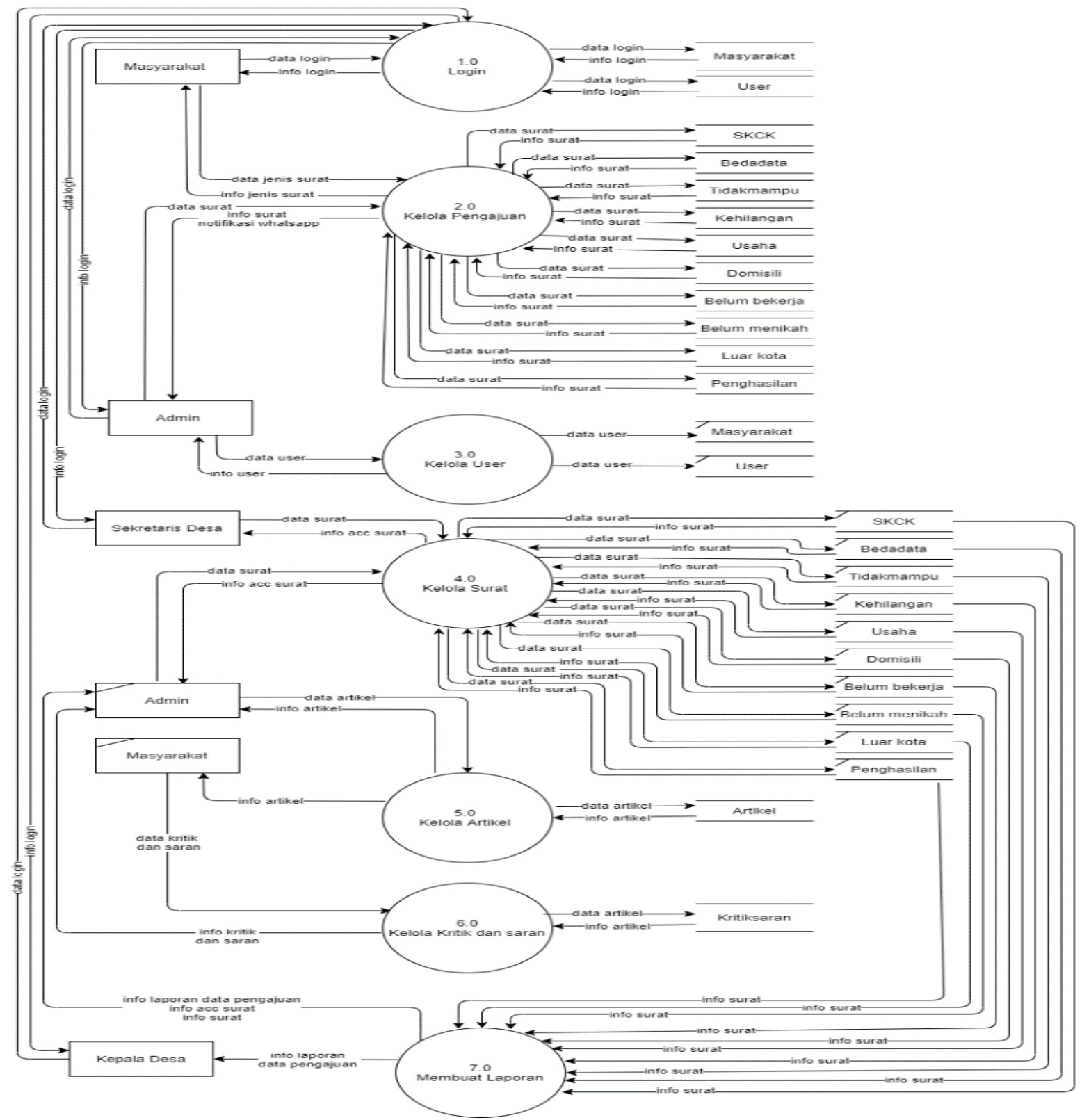

Gambar 3. DFD Level 1

3. ERD

Entity Relationship Diagram (ERD) merupakan diagram yang menjelaskan hubungan antara entitas yang ada pada system. Di dalam sistem aplikasi pelayanan administrasi kependudukan berbasis wen ini terdapat 13 entitas yang saling berhubungan yaitu masyarakat, user, beda data, kehilangan, tidak mampu, skck, usaha, domisili, belum bekerja, belum menikah, luar kota, artikel, dan penghasilan.

4. Implementasi

a. Implementasi Tampilan Website Profil Desa Sidakangen

Pada halaman awal website profil Desa Sidakangen ini, ditampilkan halaman yang menghubungkan ke halaman yang ingin dikunjungi. Serta terdapat informasi mengenai profil balaidesa Sidakangen. 


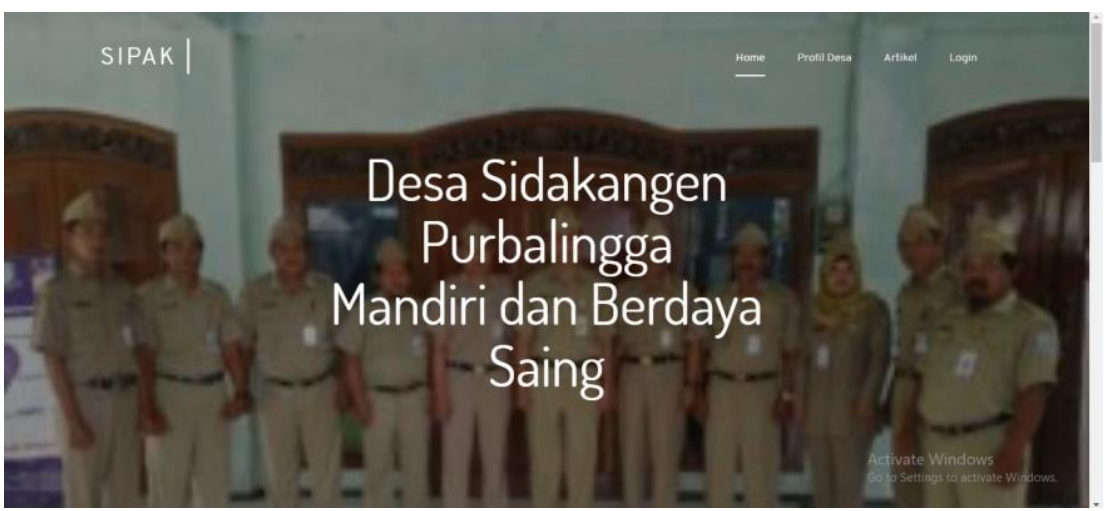

Gambar 2. Implementasi Tampilan Website Profil Desa Sidakangen

b. Implementasi Tampilan Halaman Artikel

Halaman Artikel merupakan halaman yang menampikan daftar artikel yang telah dipublikasikan oleh admin dan dapat diakses oleh pengujung website.

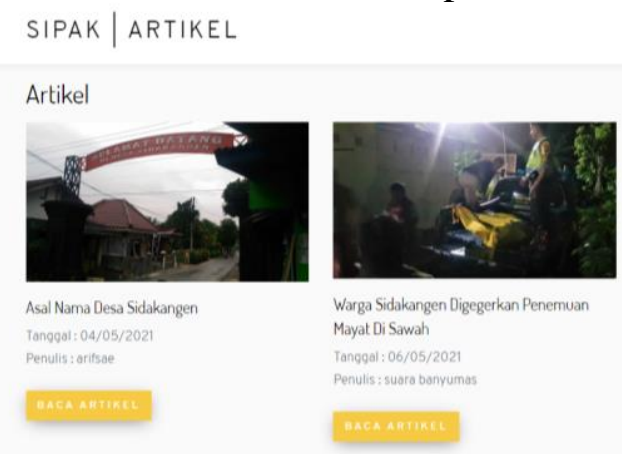

Gambar 3. Implementasi Tampilan Halaman Artikel

c. Implementasi Tampilan Halaman Pengajuan Surat

Halaman Pengajuan Surat merupakan halaman yang digunakan untuk melakukan pengajuan surat oleh masyarakat sesuai dengan kebutuhan/keperluan masyarakat dengan mengisi form yang tersedia pada sistem. Pada halaman tersebut terdapat informasi berupa informasi riwayat pengajuan dan status pengajuan.
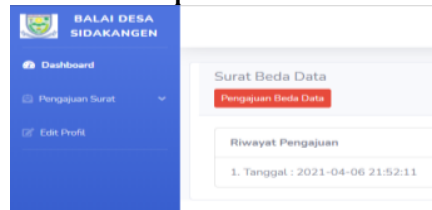


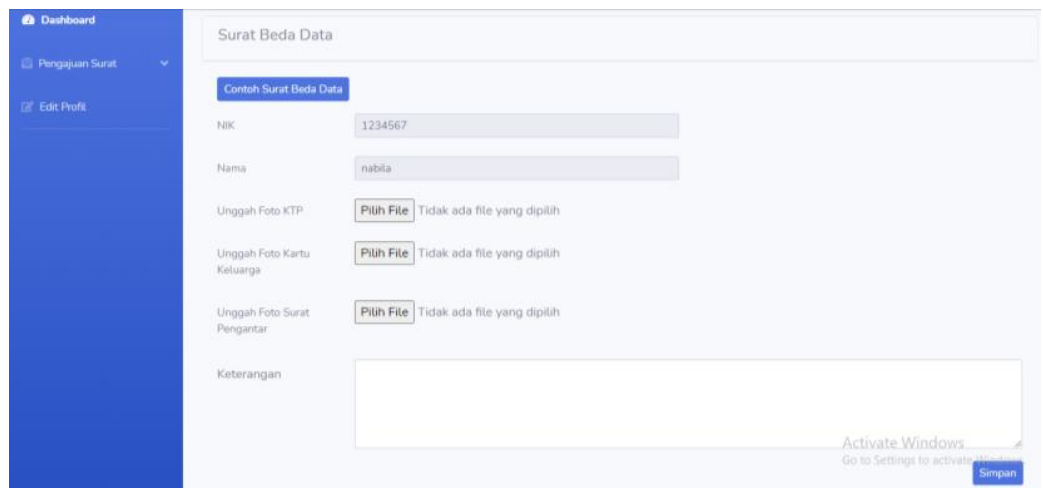

Gambar 4. Implementasi Tampilan Halaman Surat Pengajuan Masyarakat

\subsection{Tahap Penguji}

a. Pengujian Blackbox

Tahap pengujian sistem ini dilakukan dengan menggunakan metode blackbox Testing. Blackbox Testing merupakan suatu model atau metode pengujian perangkat lunak yang difokuskan pada fungsionalitas dari perangkat lunak yang diuji. Sistem Informasi Pelayanan Administrasi Kependudukan Berbasis Web ini sudah dilakukan pengujian pada fungsi operasionalnya. Adapun rencana pengujiannya diuraikan pada Tabel 3 berikut.

Tabel 2. Hasil Pengujian

\begin{tabular}{llc}
\hline \multicolumn{1}{c}{ Kebutuhan User } & Kode URS & Hasil Pengujian \\
\hline Melakukan Login dengan username dan password & URS-SIPAK-1 & Terpenuhi \\
Membuat akun & URS-SIPAK-2 & Terpenuhi \\
Dapat mengubah akun & URS-SIPAK-3 & Terpenuhi \\
Dapat melakukan pengajuan surat & URS-SIPAK-4 & Terpenuhi \\
Dapat melihat status pengajuan surat & URS-SIPAK-5 & Terpenuhi \\
Dapat melihat artikel dan profil desa & URS-SIPAK-6 & Terpenuhi \\
Dapat melakukan pengajuan kritik dan saran & URS-SIPAK-7 & Terpenuhi \\
Melakukan Login dengan username dan password & URS-SIPAK-8 & Terpenuhi \\
Dapat menghapus User & URS-SIPAK-9 & Terpenuhi \\
Dapat melihat Pengajuan Surat & URS-SIPAK-10 & Terpenuhi \\
Dapat mengedit Surat & URS-SIPAK-11 & Terpenuhi \\
Dapat Mengkonfirmasi Persetujuan (ACC Surat) & URS-SIPAK-12 & Terpenuhi \\
Dapat Mencetak Surat Pengajuan & URS-SIPAK-13 & Terpenuhi \\
Dapat mencetak Laporan Surat & URS-SIPAK-14 & Terpenuhi \\
Dapat menambahkan artikel kegiatan desa & URS-SIPAK-15 & Terpenuhi \\
Notifikasi WhatsApp & URS-SIPAK-16 & Terpenuhi \\
Dapat melihat kritik dan saran & URS-SIPAK-17 & Terpenuhi \\
Dapat menghapus artikel kegiatan desa & URS-SIPAK-18 & Terpenuhi \\
Melakukan Login dengan username dan password & URS-SIPAK-19 & Terpenuhi \\
Dapat melihat konfirmasi persetujuan (ACC Surat) & URS-SIPAK-20 & Terpenuhi \\
Dapat Menghapus Pengajuan Surat & URS-SIPAK-21 & Terpenuhi \\
Melakukan Login dengan username dan password & URS-SIPAK-22 & Terpenuhi \\
Dapat melihat laporan data Pengajuan & URS-SIPAK-23 & Terpenuhi \\
\hline
\end{tabular}




\section{b. Kuesioner MOS (Mean Opinion Score)}

Tahap pengujian selanjutnya, menggunakan uji MOS (Mean Opinion Score). MOS merupakan metode dalam mengukur kinerja dan kualitas dari sistem yang dibangun. Misal "Sangat Bagus" atau "Sangat Buruk". Pengujian ini dilakukan dengan melibatkan beberapa responden untuk mencoba menggunakan sistem, kemudian meminta untuk memberikan penilaian dengan rentang 1 sampai dengan 4. Dimana nilai 1 menyatakan nilai terburuk dan nilai 4 menyatakan nilai terbaik. Kemudian dihitung rata-rata penilaian dari seluruh responden sehingga diperoleh nilai Mean Opinion Score dari sistem tersebut. Untuk pengujian MOS yang dilakukan ini berbasis User Acceptance Test (UAT). UAT adalah suatu proses pengujian yang dilakukan oleh pengguna dengan hasil output sebuah dokumen hasil uji yang dapat dijadikan bukti bahwa software sudah diterima dan sudah memenuhi kebutuhan yang diminta[15]. UAT ini dilakukan oleh 5 responden dengan 10 pertanyaan terkait sistem yang dibangun penulis

Tabel 3. Hasil Survey Pengujian MOS

\begin{tabular}{|c|c|c|c|c|c|}
\hline No & Pertanyaan & SS & $\mathbf{S}$ & KS & TS \\
\hline 1. & Sistem SIPAK mudah dioperasikan & 5 & & & \\
\hline 2. & Sistem SIPAK menarik untuk digunakan & 3 & 2 & & \\
\hline 3. & Tampilan (user interface) dari sistem SIPAK responsive & 4 & 1 & & \\
\hline 4. & Sistem SIPAK sangat memudahkan masyarakat dan Perangkat Desa & 5 & & & \\
\hline 5. & $\begin{array}{l}\text { Respon waktu mengakses fitur tiap sistem berlangsung cepat dan } \\
\text { stabil }\end{array}$ & 3 & 2 & & \\
\hline 6. & Sistem SIPAK menampilkan data yang sesuai & 5 & & & \\
\hline 7. & Tata letak informasi yang ditampilkan oleh sistem sangat jelas & 4 & 1 & & \\
\hline 8. & Fitur pada sistem SIPAK sudah lengkap & 3 & 2 & & \\
\hline 9. & Tidak pernah mengalami error/gangguan saat menjalankan sistem & 2 & 3 & & \\
\hline 10. & Informasi pada SIPAK mudah dipahami & 4 & 1 & & \\
\hline
\end{tabular}

Dari hasil analisa pengujian yang dilakukan dengan sistem berbasis user acceptance test maka nilai MOS diperoleh ke dalam presentase sebagai berikut :

a. $\quad 100 \%$ responden menyatakan sistem SIPAK mudah dioperasikan

b. $\quad 90 \%$ responden menyatakan sistem SIPAK menarik untuk digunakan

c. $\quad 95 \%$ responden menyatakan tampilan (user interface) dari sistem SIPAK responsive

d. $100 \%$ responden menyatakan sistem SIPAK sangat memudahkan Masyarakat dan Perangkat Desa

e. $90 \%$ responden menyatakan Respon untuk mengakses fitur tiap sistem berlangsung cepat dan stabil

f. $\quad 100 \%$ responden menyatakan Sistem SIPAK menampilkan data yang sesuai

g. $\quad 95 \%$ responden menyatakan Tata letak informasi yang ditampilkan oleh sistem sangat jelas

h. $\quad 90 \%$ responden menyatakan Fitur pada sistem SIPAK sudah lengkap

i. $\quad 85 \%$ responden menyatakan Tidak pernah mengalami error/gangguan saat menjalankan sistem

j. $\quad 95 \%$ responden menyatakan Informasi pada SIPAK mudah dipahami

\subsection{Tahap Pemeliharaan}

Tahap pemeliharaan sistem informasi ini secara umum dapat dilakukan dengan cara melakukan backup pada kode sistem tersebut dan melakukan penjagaan terhadap malware, virus, atau program bahaya lainnya yang akan mengganggu jalannya sistem. Tahap pemeliharaan sistem dilakukan secara berkala ketika sistem sudah mulai digunakan. Selain itu, tujuan pemeliharaan sistem juga 
dapat berguna untuk mendapatkan feedback dari pengguna berupa saran yang dapat membantu memperbaiki sistem di masa yang akan datang.

\section{KESIMPULAN}

Berdasarkan hasil analisa kebutuhan sistem dan kebutuhan pada Sistem Informasi Pelayanan Administrasi Kependudukan Desa Sidakangen Purbalingga sebagai mana yang telah di bahas pada bab IV dapat diambil beberapa kesimpulan yaitu Kegiatan yang berjalan saat ini mengenai Administrasi Kependudukan pada Desa Sidakangen Purbalingga belum didukung oleh Sistem Informasi Pelayanan Administrasi Kependudukan, dimana belum adanya sistem yang digunakan untuk melakukan pengelolaan data administrasi kependudukan agar dapat digunakan secara berkelanjutan. Hal ini dikarenakan pengelolaan data administrasi kependudukan masih menggunakan MS. Office. Untuk itu dibutuhkan sebuah Sistem Informasi Pelayanan Administrasi Kependudukan Berbasis Web untuk mengintegrasikan seluruh data pelayanan administrasi agar dapat digunakan secara maksimal.

Penelitian Pengembangan ini menghasilkan Sistem Informasi Pelayanan Administrasi Kependudukan Berbasis Web yang dapat melakukan pengelolaan pelayanan administrasi seperti pembuatan surat keterangan dan surat pengantar, serta laporan pendukung lainnya.

\section{DAFTAR PUSTAKA}

[1] Kemendagri, Permendagri Nomor 30 Tahun 2006 Tentang Tatacara Penyerahan Urusan Pemerintahan Kabupaten dan Kota Kepada Desa, Jakarta: Indonesia, 2006.

[2] H. Jogiyanto, Analisis dan Desain Sistem Informasi Edisi III, Yogyakarta: Andi, 2005.

[3] A. Kadir, Pengenalan Sistem Informasi Edisi Revisi, Yogyakarta: Andi, 2014.

[4] A. Mulyanto, Sistem Informasi Konsep dan Aplikasi, Yogyakarta: Pustaka Belajar, 2009.

[5] Suparlan, "Pengertian Pelayanan," 10 November 2016. [Online]. Available: http://www.seputarpengetahuan.co.id/2016/10/pengertian-pelayanan-menurut-para-ahlilengkap.html.

[6] Moenir, Manajemen Pelayanan Umum di Indonesia, Jakarta: Bumi Aksara, 2005.

[7] S. Hanadayaningrat, Pengantar Studi Ilmu Administrasi dan Manajemen, Jakarta: Gunung Agung, 1985.

[8] Kusrini, Konsep dan Aplikasi Sistem Pendukung Keputusan, Yogyakarta: Andi, 2007.

[9] A. Kristanto, Perancangan Sistem Informasi dan Aplikasinya, Yogyakarta: Gaya Media, 2008.

[10] Fathansyah, Basis Data, Bandung: Informatika, 2012.

[11] Rohi Abdulloh, 7 In 1 Pemrograman Web untuk Pemula, Jakarta: PT Elex Media Komputindo, 2018.

[12] Roger S. Presman, Rekayasa Perangkat Lunak, Yogyakarta: Andi, 2012.

[13] e. Chindra saputra, "Analisis dan Perancangan Sistem Informasi Administrasi Kependudukan pada Desa Kota Karang," Manajemen Sistem Informasi , p. 592, 2017.

[14] A. N. Taufik, "Rancang Bangun Sistem Informasi Administrasi Kependudukan (Studi Kasus Desa Prembun Kecamatan Tambak Kabupaten Banyumas)," Skripsi Universitas Jenderal Soedirman, Purbalingga, 2015.

[15] a. k. Efy widyawati, "Rancang Bangun Aplikasi Kependudukan Berbasis Web di Desa Kedungrejo Waru-Sidoarjp," Manajemen Informatika, pp. 171-179, 2016. 


\section{Halaman Ini Dikosongkan}

